\title{
Rezensionen | Book Reviews
}

Gethmann, Carl Friedrich et al. (2004): Gesundheit nach Maß? Eine transdisziplinäre Studie $z u$ den Grundlagen eines dauerhaften Gesundheitssystems. Forschungsberichte der Interdisziplinären Arbeitsgruppen der Berlin-Brandenburgischen Akademie der Wissenschaften: Band 13, Berlin (347 Seiten, gebunden, Akademie-Verlag, ISBN 3-05-004103-X)

Die Autoren des Bandes Gesundheit nach Maß? erheben den (gewaltigen) Anspruch, jenseits der tagesaktuellen und kurzatmigen Reformpolitik (so genannte "Ad-hoc-Interventionen«) im Gesundheitswesen mit ihrer Studie die mittel- bis langfristigen Grundlagen für eine grundsätzliche Umgestaltung des deutschen Gesundheitssystems entwickelt zu haben (6). Ein Systemwechsel sei wegen der großen Herausforderungen wie z.B. dem demographischen Wandel, dem medizinisch-technologischen Fortschritt und dem europäischen Integrationsprozess unvermeidbar.

Zunächst werden anthropologische und ethische Grundüberlegungen über Gesundheit, Krankheit und Gesundheitsstandards angestellt und die Frage aufgeworfen, wer auf welche Weise Standardisierungen und Normierungen (von sozialstaatlichen Leistungen und medizinischen Interventionen) in der Gesundheitsversorgung bestimmen sollte (9 ff.). Die Studie mündet schließlich in grundlegende Reformvorschläge, welche den Antagonismus zwischen der Individualität des Arzt-Patienten-Verhältnisses (75 ff.) und der für notwendig erachteten Effizienzsteigerungen in der Gesundheitsversorgung vermittels der Setzung von "Gesundheitsstandards« (Iog ff.) in einem »Reformmodell für mehr Wettbewerb und Eigenverantwortung « ( $187 \mathrm{ff}$.) aufzuheben versuchen.

Die kurzfristigen und (noch) systemimmanenten Reformschritte bestehen aus einer stärkeren Privatisierung und Kommerzialisierung der stationären Versorgung, der Entstaatlichung und Entkommunalisierung des Gesundheitswesens sowie der Förderung von Prävention und Gesundheitsförderung, wobei letztere vor allem durch eine verstärkte Eigenverantwortung erreicht werden soll, was den Grundideen der Ottawa-Charta, dem Schlüsseldokument der Gesundheitsförderung, allerdings völlig entgegensteht. Der Gesundheitsstatus und die Gesundheitschancen von Individuen werden durch die (ungleiche) Verteilung von Bildungschancen, beruflichen Entwicklungsmöglichkeiten und ausreichenden Einkommen determiniert, deren negative gesundheitlichen Effekte durch das bloße Einfordern von Eigenverantwortung wohl kaum kompensiert werden können.

Der längerfristige Umbau des Gesundheitssystems ruht schließlich auf vier Säulen. Erstens wird eine Mindestversicherungspflicht für alle Bürger bei weitgehender Wahlfreiheit eingeführt, wobei der Leistungskatalog in Grundleistungen und Zusatzleistungen differenziert werden soll. Zusatzleistungen sollen u.a. als individuelle Gesundheitsleistungen (so genannte $I G E L$ ) privat aufgebracht werden. Die Autoren versäumen es jedoch, klare Kriterien aufzuzeigen, wie die Mindestversicherungspflicht zu gestalten wäre. Zweitens soll eine neue Anbieterpluralität geschaffen und hierfür insbesondere das Vertragsmonopol der Kassen- 
ärztlichen Vereinigungen aufgebrochen werden. Das Sicherstellungsmonopol für die Gesundheitsversorgung müsse daher entweder den Kassen übereignet oder aber öffentlich ausgeschrieben werden. Drittens sollen die politisch-institutionellen Rahmenbedingungen dahingehend verändert werden, dass materielle Ziele und Verteilungskriterien durch Gesetz festgelegt werden, ansonsten jedoch den Subjekten (Versicherte, Versicherungsunternehmen, Anbieter) des entstehenden Gesundheitsmarkt weitgehende Vertrags- und Entscheidungsfreiheit zugestanden werden. Durch nationale Wettbewerbsprozesse und verfassungsrechtliche Konsequenzen der EU-Integration sehen die Autoren sogar die Legitimation des Gemeinsamen Bundesausschusses (G-BA), des zentralen Gremiums der Gemeinsamen Selbstverantwortung, in Frage gestellt. Statt seiner plädieren die Autoren für eine stärkere staatliche Gewährleistungsaufsicht, welche die traditionelle Gewerbeaufsicht mit einem staatlichen Regulierungsauftrag verbindet. Die Rolle der Akteure des G-BA wäre auf die Beratung der staatlichen Gewährleistungsaufsicht zurückgeführt. Schließlich plädieren die Autoren - viertens - auf der Finanzierungsseite für eine »Bürgerpauschale» (207 ff.), welche den "sozialen Ausgleich" (209) aus dem Versicherungssystem herausnimmt und einen "Umstieg auf mehr Kapitaldeckung" (209 ff.) vornimmt und die Gesetzliche mit der Privaten Krankenversicherung integriert.

Im Ergebnis entstünde ein privatrechtlich organisiertes Gesundheitssystem, welches frappierend an das seit dem oI.0I.2006 realisierte niederländische Modell erinnert (siehe dazu auch den Anhang der Studie: 239 ff.). Eine solidarische Gesundheitsversorgung, die zum einen den gleichen Zugang aller Bürger zu qualitativ hochwertigen Leistungen sichern und zum anderen sich dem Abbau sozial bedingter gesundheitlicher Ungleichheiten widmen sollte, würde mit der Realisierung dieses Reformmodells freilich von der Agenda verschwinden. Die vielen disziplinären Blindflecken und das konsequente Ignorieren von abweichenden Diskurspositionen werfen zudem die Frage auf, ob hier seriöse Politikberatung gemacht oder vielleicht eher doch wissenschaftliche Gesinnungsethik betrieben wird.

Kai Mosebach, Universität Frankfurt am Main

\section{Howell, David R. (ed.) (2005): Fighting Unemployment. The Limits of Free Market Orthodoxy, Oxford (368 pages, hardcover, Oxford University Press, ISBN 0-I9-5I6584-5)}

David Howell has edited an outstanding and overdue collection of papers that successfully reveals the "[1]imits of Free Market Orthodoxy" as the subtitle reads. The »Free Market Orthodoxy « consists of two elements. At its core is the assertion that labor market outcomes in the medium term are determined by labor market institutions (rather than, say, demand on goods markets). This is often referred to as the NAIRU hypothesis. In an extension, sometimes referred to as the Unified Theory, Orthodoxy also claims that welfare states by reducing wage dispersion cause unemployment since technological trends (or pressures from international trade) dictate greater wage inequality, which can only be countered at 
the expense of unemployment of the less skilled. The papers offer a critical evaluation of these hypotheses at a consistently high level of scholarly quality. What makes the volume under review unique is not that it reveals that these arguments are flawed (this has been done before), but the patience with which the authors demonstrate, based on cross section as well as on time panel data as well as on country studies, that the evidence fails to support the claims of the »IMF-OECD-Orthodoxy«. The careful analysis and the rich information contained in the book makes it indispensable to anyone who is interested in the functioning (or non-functioning) of labor markets in OECD countries.

After an introduction summarizing the issues at stake the book consists of cross country studies on wage compression and unemployment performance (by Howell and Huebler) and on labor market institutions and unemployment performance (by Baker et al.) respectively, followed by six articles with countries studies, usually discussing two countries. These include papers on Canada (by Stanford), the USA and UK (by Schmitt and Wadsworth), Ireland and New Zealand (by Glyn), Spain (by Munoz de Bustillo Llorente), Germany and Netherlands (by Schettkat), and Denmark and Sweden (by Plougmann and Madsen). Finally a conclusion (by Howell) makes some remarks on important countries left out (especially France and Italy) and ties the previous discussion into the big picture.

The chapters are rich in material and cannot be done justice in a short review. The following comments are necessarily subjective. Baker et alii's chapter on labor market institution is probably the most solid analysis of the cross country and panel evidence available as of yet. Its strength is not only the compilation of a data set that extends existing data back into the 1960 and a careful discussion of regression results, but a serious comparative discussion of the existing literature. It is symptom of the sad state of affairs in this area of research that the latter point, which ought to be a basic in academic writing, becomes a major achievement. However, much of the literature makes grand claims based on regression coefficients that are implausible to the common sense (see also Freeman 2005 for telling examples) and/or does not offer a serious comparison with related and contradicting work. Baker et al. find »no meaningful relationship of [the] OECD measure of labor market deregulation and shifts in the NAIRU« (IO7). Moreover, bargaining coordination consistently shows a negative effect on unemployment rates, i.e. the opposite of what the orthodox view would hold. Among the country studies, notable findings include that the tremendous improvement in unemployment rates in Ireland took place basically without labor market deregulation but rather within a social pact between government, employers and unions (Chapter 6), that the labor market institutions between the Netherlands and Germany are now remarkably similar (and thus unable to explain their different labor market performances: Chapter 8), and that Sweden since the mid-I990s had a labor market performance equally impressive, if less noticed, as Denmark (both heavily relying on active labor market policies: Chapter 9). Chapter io offers an instructive exercise in contrasting not the USA and Europe, but the USA with Austria, Netherlands, and Sweden on the one hand and Germany, France, and Italy on the other hand. While all these European economies represent extensive welfare states, the former's unemployment rates are equal or superior to the USA, the latter's are worse. 
There are two shortcomings of the book that I would like to note. First, while Chapter 3 uses OECD indicators for unemployment benefits and other welfare state measures, the country chapters do not refer much to the dataset. This gives rise to inconsistencies or at least open questions. New Zealand is praised as a poster child of orthodox policies by the OECD and criticized by Glyn. Table I.2 (identical to Table IO.I), however, indicates no changes in either unemployment benefits, their duration, or employment protection measures! Moreover, some of the chapters question whether these indicators tell us much about economic realities (e.g. the chapter on Spain). What should the reader make of this? Have the OECD data only be used to show that they do not explain much? Or do the OECD measures tell us something meaningful in a cross country context? ${ }^{\text {? }}$ A discussion of the plausibility of the data used in Chapters 2 and 3 throughout the country studies would have been desirable.

Second, the book is confined to a criticism of the orthodox position. Any complaint about the lack of an alternative explanation would be beside the point. One issue that arises consistently in the various chapters is that the successful countries mostly defied OECD wisdom and actively utilized centralized collective bargaining as part of social pacts that are sometimes called "supply-side corporatism«. If so, is it a mere coincidence that only small countries have followed this strategy so far? Could it also work in larger economies? Moreover, the refutation of the "one size fits all " policies and the call for "high levels of social consensus and social stability« (332) are a long way from concrete policy suggestions. How does one bring about "social consensus«? To be fair, Howell and co-authors have contributed their share by writing this book, it is for the rest of us to elaborate the missing chapters with an empirically grounded alternative explanation of unemployment and to derive feasible employment policies.

\section{Engelbert Stockhammer, Vienna University of Economics and Business Administration}

\section{Galbraith, John Kenneth (2004): The Economics of Innocent Fraud, New York (62 pages, paperback, Houghton Mifflin, ISBN 0-6I8-01324-5)}

Even before his recent death in April 2006 - at the age of 97 - John Kenneth Galbraith had become a legend as one of the greatest economists of our times. The Canadian-born economist taught at the Ivy League universities Princeton and Harvard. He wrote over 30 books - most of them academic, some of them more journalistic, almost all of them bestsellers. Amazingly early he perceived and predicted many of the developments and tendencies that characterize mature capitalist economies. Some of the terms he coined have

I This reviewer was surprised to find that Austria has an unemployment benefit replacement rate of about 30 percent (surprisingly low) according to Table I.2, but of 50 percent (more plausible) according to Table 7.3. The Appendix of Chapter 2 offers no explanation of why the former data was used. 
become widespread - in particular the famous quote about the contrast between "private affluence" and "public squalor" from his probably best-known book The Affluent Society, written in 1958. In addition, Galbraith was often very intensely involved in U.S. politics. He was a member of Franklin D. Roosevelt's war cabinet and advisor of the Democratic U.S. Presidents John F. Kennedy and Lyndon B. Johnson. Under the Kennedy administration he even served as U.S. ambassador in India.

From the very beginning of his career, he joyfully criticized the economic mainstream and continued to do so throughout his life. Often his criticism was targeted at unrealistic assumptions that characterize the mainstream's theoretical approaches. For instance, in contrast to conventional microeconomic theory he emphasized the dominant position of big corporations in the modern economy. Moreover, he got vehemently and successfully involved in the campaign for a strong welfare state and the fight against poverty. When Galbraith published his (in hindsight last) book The Economics of Innocent Frand in 2004, a book that is again about the loss of realism in today's economy and economics, he earned considerable public attention in the U.S. and particularly in Europe, where criticism of capitalism has been on the rise for some time now.

In his last book, Galbraith aimed at uncovering different forms of contemporary »innocent fraud «. For him the gap between "prevailing opinion " - serving as the description of reality - and (economic) reality itself was of particular interest. According to Galbraith, this gap can be interpreted as fraud in the sense of a deception, which often serves the particular economic interests of certain groups of society - mostly the rich and powerful. Nonetheless it may be termed "innocent « insofar as it does not necessarily happen consciously or with evil intentions - Galbraith does not present a conspiracy theory.

The first "fraud " Galbraith uncovers is the term we often use for our economic system. As the negative associations caused by the term "capitalism " have made it unsustainable, it was replaced by the label »market economy«. This term - in Galbraith's view - suggests the dominance of anonymous markets and therefore ultimately of consumers, although in reality capitalists and big corporations continue to dominate economic life. Further frauds according to Galbraith: the claim that bureaucratic structures only exist in the public sector, but not in private firms. The belief that the state and the economy are two independent sectors, although in reality the economy often considerably influences the state (obviously so, for example, in the case of the military-industrial complex). The assumption that the business cycle or even stock prices are predictable. The belief that monetary policy can effectively influence the business cycle.

The book is very well written and argued and entertaining to read. Due to its brevity - it comprises only 62 pages - it is not astonishing that some claims, for example that of the almost complete ineffectiveness of monetary policy, cannot be treated in depth. Many readers who are already acquainted with Galbraith's work will rediscover well-known arguments. This implies that the book is an excellent and inspiring first introduction to Galbraith's voluminous work, which strongly motivates further reading. Here, Galbraith's admirably critical attitude and his struggle for a humane design of the economy and the society unfold themselves. 
Galbraith asks central questions in an entertaining and concise way, and he points out inconsistencies and contradictions in societal self-perception that often go unnoticed. This is perhaps the greatest merit of his last book, which cannot be overestimated at a time where particularly German economists barely consider such questions as appropriate any more. The fact that the German newspaper Frankfurter Allgemeine Zeitung, one of the most influential opinion leaders for the German-speaking economic and political elite, in its obituary of Galbraith denied him the status of a "real" economist, may just serve to illustrate our point and Galbraith's too; as another (hopefully) »innocent fraud «.

\section{Margit Schratzenstaller, Austrian Institute of Economic Research (WIFO), Vienna Achim Truger, Macroeconomic Policy Institute (IMK), Düsseldorf}

\section{Stockhammer, Engelbert (2004): The Rise of Unemployment in Europe. A Keynesian Approach, Northampton (2I4 pages, paperback, Edward Elgar, ISBN I-84376-4I0-5)}

Unemployment is a central problem for European economic and social development. This simple statement is today acknowledged by economists and politicians alike. Suggested remedies mostly concentrate on cutting unemployment benefits and wage costs, on making labour markets more flexible, and on improving training and semployability of the workforce, putting emphasis on individual responsibility.

In his book, Engelbert Stockhammer tries to show that the "standard " answers to unemployment cannot be sufficiently underpinned empirically, and that Keynesian explanations incorporating demand deficiencies fare better. Furthermore, Stockhammer makes an attempt to explain the alleged lack in aggregate demand, and attributes this to "financialisation", the increased investment by companies in financial markets rather than production capacities.

The first half of The Rise of Unemployment in Europe is thus dedicated to the NAIRU (non-accelerating inflation rate of unemployment) theory placing the blame for European unemployment on inflexible labour markets. This is compared and contrasted with a Keynesian view of unemployment. Stockhammer succeeds in drawing a differentiated picture of NAIRU and Keynesian theories, demonstrating that they have quite a few traits in common, among them distributional conflicts as the source of inflation, their focus on institutions and a non-market clearing outcome. On the other hand, Stockhammer clearly points out the differences between the two concepts. In Keynesian models demand plays a pivotal role for the determination of unemployment, and a lack of demand serves as the main explanation for current unemployment rates in Europe. In particular, hesitant investment is made responsible for resource underutilisation. Stockhammer provides statistical evidence confirming his claims that Keynesian theory is better positioned to explain and remedy the unemployment rates experienced by Europe.

The second half of the book concentrates on the explanation of the slowdown in investment. The verbal analysis is explicitly class-oriented, taking into account the - admittedly 
blurred - groups of workers, managers and shareholders. At the core of this development the author makes out a plausible shift in the power balance within European societies from workers to shareholders. The liberalisation of capital markets is seen as the cause and the vehicle by which the latter were able to discipline managers and at the same time to align managers' interests with theirs. Thus, in accordance with the post Keynesian theory of the firm, Stockhammer argues that profit was given more importance than growth. This led to financialisation, the increasing investment in financial assets rather than in production capacity. This assumption is integrated by Stockhammer into an estimation of investment that mixes (post) Keynesian and neoclassical elements. It performs reasonably well in explaining the decline in European investment which paradoxically went along with a rise of the profit share in income.

In the text, Stockhammer on the one hand does point to fundamental differences between (post) Keynesian and neoclassical concepts such as fundamental uncertainty or behavioural assumptions. He also clearly shows the differences with respect to the place demand is given, and in particular to policy outcomes. And his analysis identifies which groups profit from which theories and policies, giving it a distinct class focus.

On the other hand, Stockhammer cannot avoid the difficulties involved in using quantitative methods for (post) Keynesian concepts. In the empirical econometric analysis, differences between neoclassical and (post) Keynesian economics are reduced to variations in explanatory (and explained) variables. Keynesian and neoclassical specifications are estimated in one single equation. At one point, Stockhammer argues that (post) Keynesian and neoclassical theories of investment are very similar, and that (post) Keynesian concepts could well be formulated under utility maximisation assumptions. To some Post-Keynesians this may seem too much of an embrace, seeing that Keynesianism already almost suffocated once in the neoclassical synthesis.

Nevertheless, this capacity to cross bridges pays off when Stockhammer successfully intertwines Marxian-type class analysis and (post) Keynesian concepts and methods. Given the critical and sometimes hostile debate between the two schools, the extent to which an integrated analysis is mutually beneficial might be somewhat surprising. The author demonstrates that different strands of heterodox economic analysis are not only compatible, but can profit substantially in grasping pressing real-world problems.

The rise of unemployment in Europe is an economist's book for economists, and it presents a powerful rejection of what is dubbed the "NAIRU story« of European unemployment of overly protective social security and rigid labour markets. Backed up by thorough theoretical and econometric analysis, it demonstrates meticulously that demand deficiencies and liberalised financial markets are at the heart of European unemployment. Thus, Stockhammer provides substantiated arguments for the scientific and political debate, arguing forcefully that unemployment has to be fought on the goods and not on the labour markets.

Miriam Rehm, Vienna University of Economics and Business Administration 
Heintze, Cornelia (2005): Wohlfahrtsstaat als Standortvorteil. Deutschlands Reformirrweg im Lichte des skandinavischen Erfolgsmodells, Leipzig (I86 Seiten, broschiert, RosaLuxemburg-Stiftung Sachsen e.V., Texte zur politischen Bildung H. 33, ISBN 3-89819-2I7-2)

Cornelia Heintze hat ein wissenschaftliches und politisches Buch geschrieben, in dem sie die dominanten neoliberalen Wirtschafts-Glaubenssätze in Wissenschaft, Medien und Politik zu enttarnen und zu widerlegen versucht. Heintze unterzieht den "neoliberalen Elitenkonsens" (S. I3) in Deutschland einem empirischen Praxistest und vergleicht den beschäftigungspolitischen Erfolg verschiedener westlich-kapitalistischer Staaten. Sie zeigt anhand von OECD- und EU-Daten, dass sowohl der skandinavische als auch der angelsächsische Weg beim Abbau der Massenarbeitslosigkeit erfolgreich ist, wobei der Erfolg der skandinavischen Länder mit steigenden Realeinkommen, hohen Steuern und Sozialabgaben sowie einem hohen Anteil öffentlicher Beschäftigung (vor allem im Bildungs- und Gesundheitswesen) einhergeht, was neoliberalen Kausalitätsannahmen zufolge zu wirtschaftlichem Ruin führen müsste. Heintze zeigt die Überlegenheit des skandinavischen Modells gegenüber den angelsächsischen Ländern auf, indem sie weitere Indikatoren, wie den Abbau sozialer Ungleichheit, Nachhaltigkeit in der Haushalts- und Finanzpolitik, Gleichstellung, Bildung, Klimaschutz / Umwelt, Entwicklungspolitik und die Gesundheitsversorgung in die Betrachtung einbezieht. Der vom wirtschaftspolitischen Mainstream oft beschworene Trade-Off zwischen Arbeitslosigkeit und Armut/sozialer Ungleichheit ist nicht zwingend, denn Dänemark, Schweden, Finnland und Norwegen verfolgen erfolgreich einen egalitären Entwicklungspfad mit niedriger Arbeitslosigkeit und einer geringen (Kinder-)Armutsquote.

Die Autorin macht die skandinavische Kultur für den Erfolg des Modells verantwortlich. Spezifische Wertorientierungen, Wahrnehmungsweisen und daraus folgende Denkund Handlungsmuster führten dazu, dass sich in Skandinavien eine wirtschaftlich leistungsfähige und beschäftigungspolitisch erfolgreiche, an sozialer Gerechtigkeit orientierte, ökologisch verträgliche und nachhaltige Entwicklung vollziehe. Dies macht Heintze an verschiedenen kulturellen Dimensionen fest: dem Grad an Machtdistanz, dem Kollektivismus / Individualismus, der Maskulinität/ Feminität, der Unsicherheitsvermeidung und der Langfristigkeitsorientierung. Mit Maskulinität/ Feminität sind jedoch nicht patriarchale versus egalitäre Gesellschaften gemeint, sondern Nationalstaaten, in denen eine feminine oder eine maskuline Kultur vorherrscht. Dieser Analyseindikator, den Heintze von Hofstede übernommen hat, reproduziert Geschlechterstereotypen, anstatt sie zu dekonstruieren.

In den skandinavischen Ländern, deren Kultur durch lediglich mäßigen Individualismus, feminine Wertorientierungen, eine geringe Machtdistanz, eine eher langfristige Orientierung und eine schwache Unsicherheitsvermeidung geprägt ist, gehören Freiheitsrechte und Wohlfahrtsstaatlichkeit ganz selbstverständlich zusammen. Die Gleichstellung im egalitär-individualistischen Modell ist weit fortgeschritten und wird mittels familienpolitischer Maßnahmen - Kinderbetreuungsinfrastruktur und familienfreundliche Arbeitswelt - gefördert. Ein Nebenprodukt der erfolgreichen Emanzipationspolitik ist die hohe Geburtenrate in den skandinavischen Ländern. Zudem betont Heintze unter anderem die 
spezifische skandinavische Lernkultur, die auf individuellen Erfolgserlebnissen basiert und nach den PISA-Studien zu sehr guten Ergebnissen führt.

Im Zentrum des Buches steht der Vergleich Deutschlands mit den skandinavischen Ländern, doch an einigen Stellen schweift der Text ab, z.B. wenn Heintze über die US-amerikanische Kultur, die dort regierenden Republikaner und den Irak-Krieg nachdenkt.

Anders als erwartet ist das letzte Kapitel zur skandinavischen Kultur nicht das beste, weil dort vor allem auf Sekundäranalysen zurückgegriffen wird - Hofstede, Pfau-Effinger, Esping-Andersen etc. - und diese Ansätze lediglich sehr locker durch diverse kulturelle Bezugspunkte verknüpft sind und vor allem dazu dienen, die thematisch unterschiedlichen politischen Argumentationen zu stützen. Etwas unbefriedigend ist auch der Schluss, in dem lediglich betont wird, dass Deutschland aufgrund der kulturellen Unterschiede wohl weniger von den skandinavischen Ländern als von seinen Nachbarstaaten lernen kann. Demgegenüber überzeugen die ersten beiden Kapitel zum Abbau der Arbeitslosigkeit und zur politischen Gesamtperformance der untersuchten Länder trotz kleinerer Mängel, wie dem Fehlen eines Vergleichs der Gesundheitsausgaben, durch eigenständige empirische und analytische Arbeiten. Es ist das Verdienst dieses Buches, dem neoliberalen Mainstream und Zeitgeist nicht nur eine kluge, weit über die Beschäftigungspolitik hinaus gehende, ganzheitliche Analyse entgegen zu stellen, sondern mit der kulturellen Prägung auch ein mögliches Erklärungsmuster für den Erfolg des skandinavischen Modells zu liefern.

Diana Auth, Universität Gießen 